\title{
Strong Site Effect Revealed by a New Broadband Seismometer on the Continental Shelf Offshore Nice Airport (Southeastern France)
}

\author{
Francoise Courboulex, ${ }^{1}$ (D) E. Diego Mercerat, ${ }^{2}$ Anne Deschamps, ${ }^{1}$ Sébastien Migeon, ${ }^{1,3}$ Marion Baques, ${ }^{1}$ \\ Christophe Larroque, ${ }^{1}$ Diane Rivet,${ }^{1}$ and Yann Hello $^{1}$
}

\begin{abstract}
A broadband seismological station (PRIMA) installed offshore Nice airport (southeastern France) reveals a strong amplification effect of seismic waves. PRIMA station was in operation for 2 years (9/2016 to 10/2018) on the outer shelf at a water depth of $18 \mathrm{~m}$. Situated at the mouth of the Var River, this zone is unstable and prone to landslides. A catastrophic landslide and tsunami already occurred in 1979 , causing 10 casualties. Given the level of seismicity of the area, it is important to infer the impact of an earthquake on this zone. We analyze the recordings of earthquakes and seismic noise at the PRIMA station by comparing them to nearby inland stations. We find that the seismic waves are strongly amplified at PRIMA at some specific frequencies (with an amplification factor greater than 10 at $0.9 \mathrm{~Hz}$ ). Using geological and geophysical data, we show that the main amplification frequency peak (at $0.9 \mathrm{~Hz}$ ) is due to the velocity contrast between the Pliocene sedimentary layer and fine-grained sediments dated from the Holocene, at about $100 \mathrm{~m}$ depth. This velocity contrast is also present along the Var valley, but the level of amplification detected on PRIMA station is larger. Using numerical simulations of seismic waves in a $2 \mathrm{D}$ model that accounts for the pinch-out geometry related to the termination of the Holocene sedimentary layer, we can partially explain this amplification. This offshore site effect could have a crucial impact on the triggering of a submarine landslide by an earthquake in this region. More generally, this effect should be taken into account for the modeling of landslides and induced tsunamis triggered by seismic waves.
\end{abstract}

Keywords: Earthquakes, site effects, landslides, offshore seismometer, seismic hazard.

Electronic supplementary material The online version of this article (https://doi.org/10.1007/s00024-019-02408-9) contains supplementary material, which is available to authorized users.

1 Université Côte d'Azur, Observatoire de la Côte d'Azur, CNRS, IRD, Géoazur, Valbonne, France. E-mail: courboulex@ geoazur.unice.fr

2 CEREMA, équipe MouvGS, Sophia Antipolis, Valbonne, France.

3 Sorbonne Université, Faculté des Sciences et Ingenierie, Paris, France.

\section{Introduction}

Ground motions generated by an earthquake depend mainly on the magnitude of the earthquake, the distance between the active fault and the site of interest, and on near-surface effects commonly referred to as site effects, which result from the interaction between seismic waves and surface lithology and/or topography.

The effect of superficial geology on seismic waves has been detected since the end of the nineteenth century (see Sanchez-Sesma and Crouse 2015 for an historical review) but it has been clearly identified and widely studied since the $M=8.0$ Mexico earthquake that strongly damaged Mexico City in 1985 (Anderson et al. 1986; Cruz-Atienza et al. 2016). Built on top of ancient lake deposits, Mexico City experiences some of the world's largest seismic site effects. Since then, several studies have been undertaken worldwide in order to detect and predict site effects in cities and to include them in seismic risk building codes. Amplification due to sedimentary layers has been quantified in several cities such as Los Angeles (Clayton et al. 2015), Tokyo (Yamanaka et al. 1989), Quito (Laurendeau et al. 2017), Port au Prince (St Fleur et al. 2016), or Amatrice in Italy (Milana et al. 2019).

Until recently, site effects studies were mainly carried out inland. This can be explained by the small number of well-calibrated broadband seismic stations installed offshore. The other reason is certainly that it is difficult to compare underwater recordings with terrestrial recordings when distances between them are large, which is often the case. 
Few studies have reported the fact that seismic waves can also be amplified offshore. Nakamura et al. (2015) demonstrated evidence for the development of long-period (10-20 s) motions using deep ocean data in Japan. Kubo et al. (2018) investigated the site effects in the $0.2-10 \mathrm{~Hz}$ frequency band on a seafloor observation network installed in the Nankai subduction zone in Japan. They found very strong amplification factors at some stations and focus on the fact that, if uncorrected, this may bias earthquake early warning (EEW) for subduction earthquakes. $\mathrm{Li}$ et al. (2017) proposed a simulation method to obtain offshore transfer functions. Recently, Gomberg (2018) realized a systematic analysis of earthquake recordings of the permanent offshore network of Cascadia and detected that a specific site amplification can be found at different stations, mainly depending on their location. She pointed out that these offshore site effects should be taken into account in the analysis of the earthquake-triggered turbidites used for paleoseismology at sea.

A correct estimation of the amplification caused by offshore sediment on continental margins is of great importance for several reasons. It is widely recognized that landslides are one of the most damaging collateral effects associated with seismic shaking. In many seismically active areas of the world, earthquake-induced landslides commonly account for a significant portion of the total impact of earthquakes (Meunier et al. 2007; Chousianitis et al. 2016). When the sources of landslides are in coastal areas, they can generate proximal tsunami waves that will reach the coastlines in only a few minutes. This phenomenon has been observed at several places (e.g. Kawamura et al. 2014; Piper et al. 1999; Wartman et al. 2013) and is a subject of preoccupation when the coasts are highly populated. Second, it is well accepted that seafloor shaking during large earthquakes promotes multiple mass-wasting events and subsequent widespread turbidity currents, depositing greater volumes of particles than those triggered by climatic events. Turbidite stratigraphy is therefore a powerful tool to evidence and characterize the occurrence of past earthquakes (e.g. Priest et al. 2017; Ratzov et al. 2015) during historical and pre-historical times as well as during periods of supercycles and superquakes (Goldfinger et al. 2013). The last reason is that in many highly populated areas, new buildings and infrastructures (port, airport, storage of dangerous materials, and power plants) are more and more often constructed on land reclaimed on the inner continental shelf without taking into account the possible offshore site effects. It is therefore crucial to detect and to quantify the amplification effects caused by superficial offshore sediment in order to use them in predictive models.

In order to test and quantify the potential amplification of seismic waves offshore, we installed a broadband seismometer near the transition between the continental shelf and the upper continental slope, at a water depth of $18 \mathrm{~m}$, offshore Nice city airport (southeastern France). This zone has the advantage of being (1) well instrumented by a network of seismic broadband stations that enables us to compare inland and offshore recordings, (2) one of the most seismically active zones of western Europe, and (3) a zone with high stakes because it previously experienced a large submarine landslide that caused a tsunami wave, causing partial destruction of the airport. This paper presents a detailed analysis of the best earthquakes and ambient noise recordings in time and frequency domains from September 2016 to October 2018.

\section{Context}

\subsection{Earthquake and Submarine Landslides in the Nice Region}

The Nice region is one of the most seismically active regions of Western Europe (Larroque et al. 2001). We know from GPS measurements that it is a slowly deforming intraplate area (Nocquet 2012). Present-day seismic activity is characterized by numerous small earthquakes rarely felt by the population and some moderate earthquakes $(\mathrm{M}>4.5)$ every 5-7 years (Courboulex et al. 2007; Larroque et al. 2001, 2016). Nevertheless, larger earthquakes causing extensive damage were also reported during historical times. The best-known event occurred in 1887 and is named the Ligurian earthquake $(\mathrm{Mw}=$ 6.7-6.9, Larroque et al. 2012). It caused the death of 600 persons along the Ligurian coast and in villages in the backcountry. This major earthquake was also 
responsible for a small tsunami (Ioualalen et al. 2014), the triggering of several small-scale submarine landslides, and the emplacement of amalgamated turbidites (Hassoun et al. 2014; Migeon et al. 2011). The occurrence of such an event today would have dramatic consequences, particularly because of the high population density on the coast along the Italian Liguria and the French Côte d'Azur.

More recently, another kind of dramatic event affected the Baie des Anges area and the city of Nice. On October 16th 1979, a submarine landslide involving a volume of $8-9 \times 10^{6} \mathrm{~m}^{3}$ of sediment affected the continental shelf-upper slope transition offshore Nice airport and generated destructive tsunami waves (Gennesseaux et al. 1980; Ioualalen et al. 2010; Kelner et al. 2016; Migeon et al. 2006; Mulder et al. 1997). The combined effect of both the landslide and the subsequent tsunami was responsible for the death of 10 people and extensive infrastructural damage. It is now well established that the 1979 landslide was not triggered by an earthquake but rather by exceptional loading caused by land-reclamation operations related to the building of a new harbor (Dan et al. 2007). Nevertheless, the upper continental slope of the Baie des Anges being regularly affected by submarine landslides (Migeon et al. 2012; Kelner et al. 2016) and seismic loading being a prominent trigger for submarine landslides (Locat and Lee 2002; Sultan et al. 2004), it is important to predict the possible effect of a future earthquake occurring in the region.

Because of the 1979 event, several studies have already characterized the stability of the Nice continental slope using morpho-bathymetry investigations (Klaucke and Cochonat 1999; Migeon et al. 2012; Kelner et al. 2016), Envisat INSAR data (Cavalié et al. 2015), in situ measurements (Stegmann et al. 2011; Steiner et al. 2015; Sultan et al. 2010), laboratory experiments (Kopf et al. 2016; Mulder et al. 1997; Stegmann and Kopf 2014), and numerical modeling (Dan et al. 2007; Steiner et al. 2015). Only a few studies (Sultan et al. 2004; Dan et al. 2007; Ai et al. 2014) have focused on the potential effects of the seismic waves of an earthquake on the airportslope stability, in order to answer the crucial question: could local seismic waves trigger a major landslide? The conclusions of these studies are controversial and depend on the level of the input seismic wave (more precisely the peak ground acceleration) taken into account in the models. Although the theoretical earthquake magnitude used in these studies was generally taken around 6-6.5, none of these studies took into account the possible amplification of waves in this zone.

\subsection{Continental Shelf/Upper Continental Slope Zone}

The Nice continental shelf is part of the northern Ligurian margin located at the junction between the western Alps and the Mediterranean basin. This passive continental margin developed during a phase of rifting that started between 34 and 28 Ma and ended around $21 \mathrm{Ma}$ (Rehault and Bethoux 1984; Séranne 1999). Today, the Ligurian margin is narrow and abrupt, without a large continental shelf. The continental slope is largely incised and displays numerous submarine canyons. These canyons developed during the Messinian event, when the Mediterranean sea level dropped by $1500 \mathrm{~m}$ (e.g. Krijgsman et al. 1999). Following the Messinian sea level drop, during the Pliocene and the Quaternary, the downstream section of the Var river was invaded by the sea and transformed into ria (Clauzon 1978; Dubar and Anthony 1995). The thick Plio-quaternary sedimentary succession, reaching several hundreds of meters and originating from the erosion of the western Alpine belt, built large Gilbert deltas lying on the deeply incised erosional relief.

Thanks to multibeam bathymetry data, we have a precise description of the present-day seafloor morphology offshore Nice airport. It is dominated by failure-related scars and their subsequent downstream chutes (erosional pathways of mass flows, Kelner et al. 2016). Around the southwestern part of the airport next to the eastern (left-hand) flank of the Var Canyon, the shelf is $70 \mathrm{~m}$ wide on average (20-280 m) and the shelf break lies between 3 and $18 \mathrm{~m}$ water depth. Along the longer airport side parallel to the runways, the continental shelf is wider and exhibits three promontories (P1, P2, P3, Fig. 1). The 1979-slide scarp (e.g. Dan et al. 2007) is located between P1 and P2, and the PRIMA seismologic station is located in the western part of P2, near the transition between the continental shelf and the upper continental slope. 


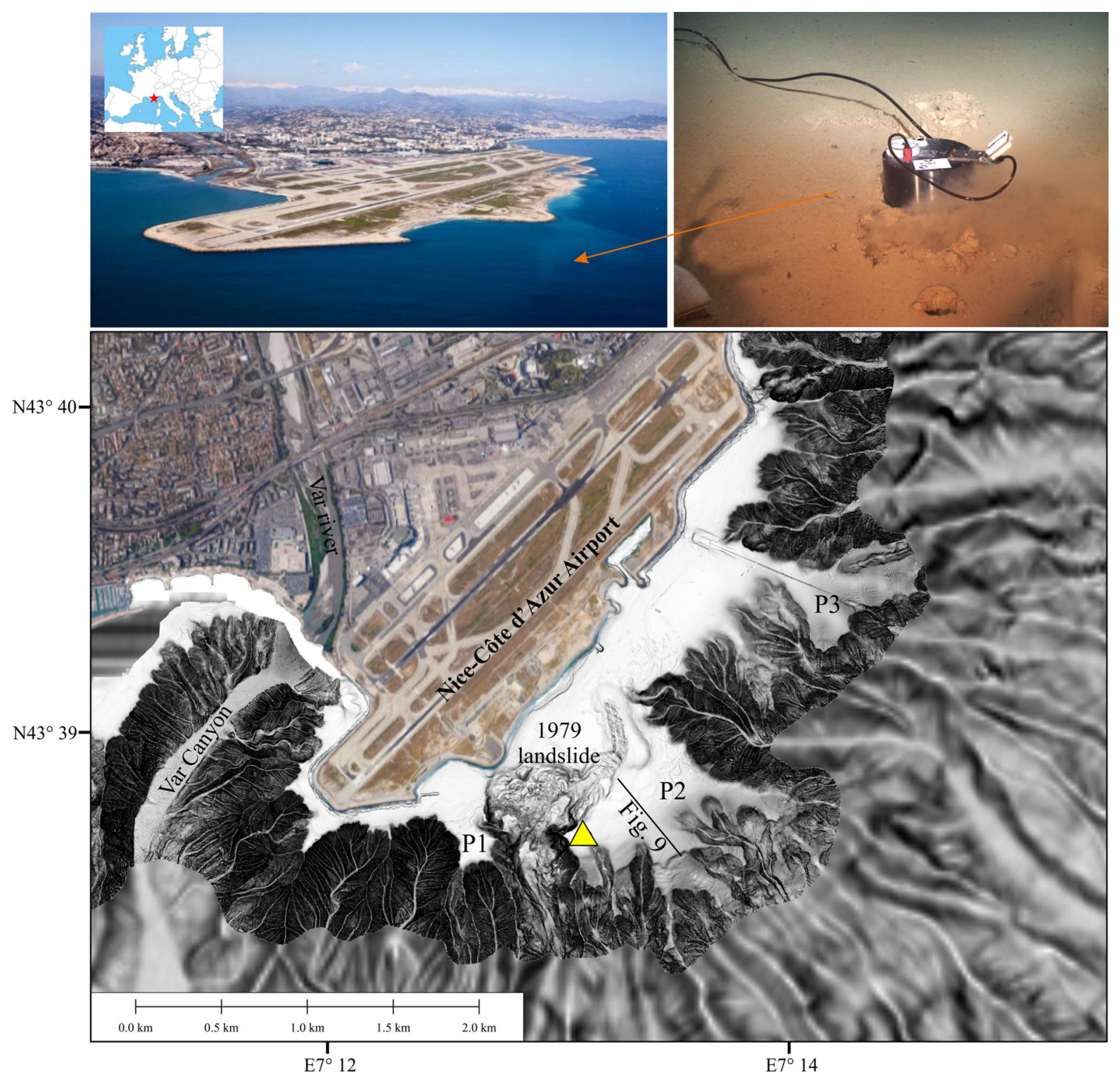

Figure 1

Top left: Photo of the airport runaways of Nice Côte d'Azur, situated at the western part of the city of Nice (southeastern France, see inset) Top right: photo of the PRIMA seismic station installed on the sediment slope of Nice airport at a depth of 18 meters, before it was covered by a semi-spherical plastic bell. Bottom: multibeam bathymetry data. The PRIMA station is located by a yellow triangle. The black line indicates the localization of the sparker profile shown on Fig. 9. The place where the destructive 1979 landslide initiated is indicated

\section{PRIMA Offshore Station and the Permanent Seismological Network}

EMSO (European Multidisciplinary Seafloor and water-column Observatory) is a large-scale, distributed, marine Research Infrastructure. It consists of ocean observation systems for the sustained monitoring of environmental processes and their interactions. The EMSO observatory nodes have been deployed at key locations in European seas, from the Arctic to the Atlantic, through the Mediterranean to the Black Sea. One of them, EMSO-Nice observatory, centered on the Nice airport continental slope, is jointly managed by IFREMER (the French Marine 
Science Research Institute) and CNRS (Centre National de la Recherche Scientifique, France). The Var Canyon, offshore Nice, is one of the most active in Europe, with turbidity currents that transfer large volumes of continent-derived material directly to the abyssal plain (Piper and Savoye 1993). As previously described, it was the site of a large landslide in 1979 (see its trace on the bathymetric map of Fig. 1); therefore the platform offshore the airport at the top of the canyon was chosen for long-term and highresolution monitoring of the slope instability, the effect of regional seismicity, and the formation of submarine canyons.

PRIMA seismological station was installed on September 26th, 2016. Its Guralp $360 \mathrm{~s}$ broadband sensor was partially buried as horizontally as possible in very soft sediment, $18 \mathrm{~m}$ below sea level (Fig. 1). It functioned perfectly for 2 months for the 3 components. The north-south component subsequently stopped working, certainly because the leveling had not been respected. It was reinstalled horizontally by underwater divers and worked very well for 6 more months. Then it suddenly stopped in October 2018. The cable had probably been cut by the anchor of a boat and the sensor damaged. The station has been reinstalled recently (December 2019) in a safer place.

PRIMA is directly connected via a seedlink server to the Géoazur seismological system (Observatoire de la Côte d'Azur), which analyzes regional seismicity for the French seismological RESIF network (RESIF RESIF 1995a, b). The signal recorded at the PRIMA station is not suitable for micro-seismicity detection and location. It presents a large amount of noise due to the airport runaways and the fact that it is buried in soft sediment.

The region of Nice is particularly well instrumented by permanent seismic stations. In the Alpes Maritimes area, 12 broadband velocimetric stations and 17 accelerometric stations measure the ground vibrations in continuous mode at a sampling rate of $100 \mathrm{~Hz}$ and $125 \mathrm{~Hz}$ respectively (Fig. 2). Data of all stations, including PRIMA, are sent continuously both to the Géoazur laboratory and to the French center for data (RESIF).

\section{Earthquake Data Analysis}

We gather the earthquakes recorded since the station installation and select the ones with the best signal-to-noise ratio (larger than 5 in the frequency range of interest). We keep two very large earthquakes $(\mathrm{M}>7.5)$ recorded at teleseismic distances (Chile and Solomon Islands), one regional earthquake (the Norcia Mw 6.5 earthquake that occurred in Italy on October 30th 2016) and three local events with magnitudes between 3 and 4 (characteristics of the events are presented in Table 1. Local events are localized on Fig. 2).

\subsection{Teleseismic Earthquake Validation}

We first analyze the signals at the PRIMA station of the two largest events that occurred at teleseismic distances (Chile and Solomon Island, Table 1) and compare them with the signals at three broadband stations: CALF, TURF and SAOF. The comparison (in velocity) of such weak signals (the largest amplitude $\sim 0.1 \mathrm{~mm} / \mathrm{s}$ was detected for the $\mathrm{Mw}$ 7.9 Solomon earthquake of January 22, 2017) can be made only for frequencies lower than $0.1 \mathrm{~Hz}$ (at higher frequencies the level of noise does not enable us to see clearly the earthquake signal). For these frequencies we find the same waveforms for the PRIMA station and the other broadband stations (see the example of the Chile earthquake on Figure Sup1). This proves that the instrumental response and the orientation of PRIMA is correct and that the amplitude of its signal can be used in further analysis. It also shows that for frequencies lower than $0.1 \mathrm{~Hz}$, no site effect is detected. Note that teleseismic earthquakes are well recorded only at broadband stations; accelerometric stations are not sensitive enough to detect such small vibrations. These stations will be used for the analysis of local and regional events in the next paragraph.

\subsection{Regional and Local Earthquakes}

We now focus on the best regional and local earthquakes recorded at the PRIMA station. As for teleseismic events, we compare the signals at PRIMA station with the one at broadband stations, but in 


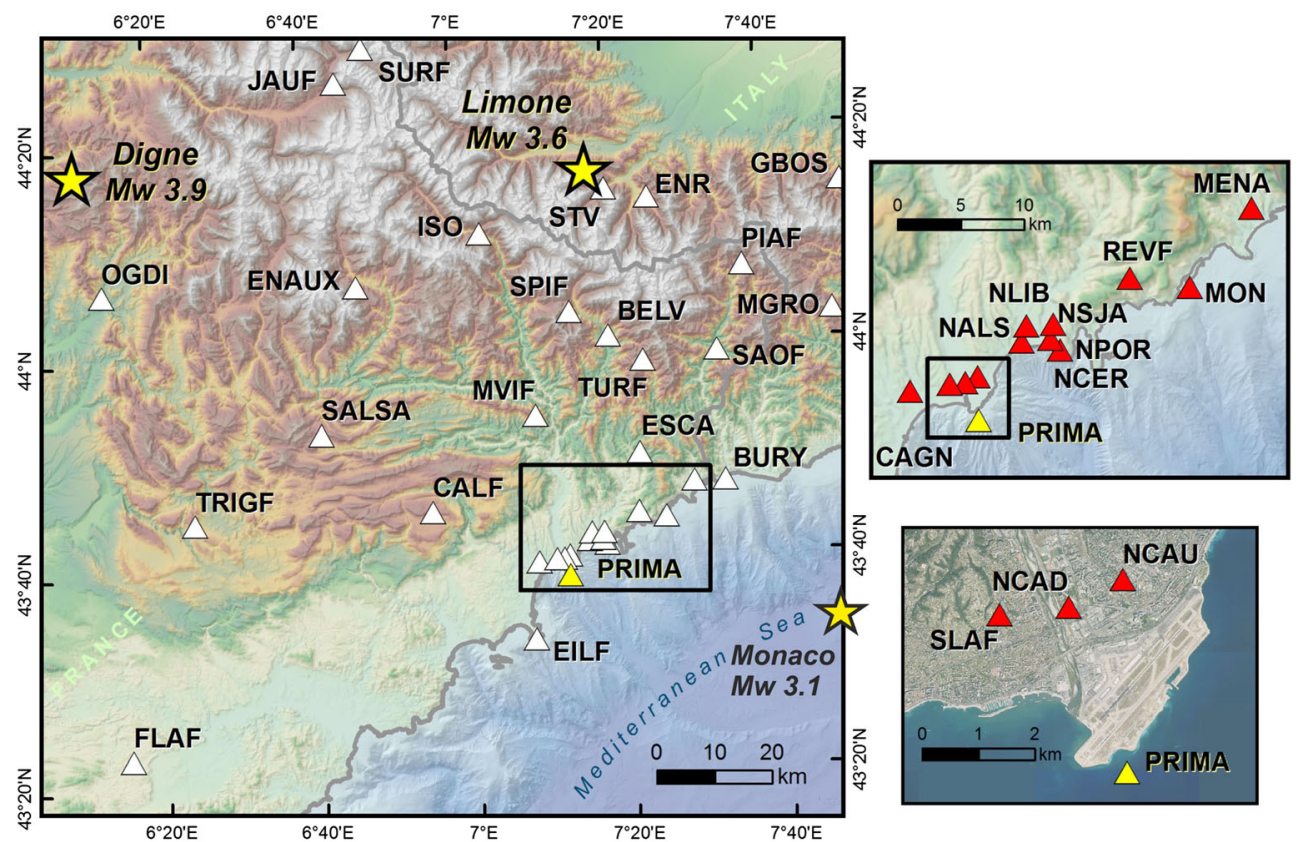

Figure 2

Left: permanent seismic network in the southeast of France (RESIF network) and west of Italy (Italian network). Each station is represented by a white triangle. Almost all the stations are equipped with both a broadband sensor and an accelerometric one, except the stations in the black rectangle around Nice that are equipped with accelerometric sensors only. The locations of local earthquakes studied in this paper are indicated by stars. Top right: zoom on the Nice area. Red triangles represent the permanent accelerometric stations (RAP-RESIF). Bottom right: zoom on the airport zone and the three stations (SLAF, NCAU, NCAD) mainly used in this study. The PRIMA station is represented by a yellow triangle

addition, we use the stations of the accelerometric network of the city of Nice (RAP-RESIF). Three stations of this network are located particularly close to Nice airport: station NCAD in the center of the Var valley, SLAU on the right-hand side of the Var river and NCAU on the left-hand side. NCAD is located on recent fluvial deposits while NCAU and SLAF are installed on conglomerates. NCAU will be our reference station for the area, although it is not really placed on hard rock. The four stations (NCAD, NCAU, SLAF and PRIMA) being located in a small zone, at a maximum distance of $3.2 \mathrm{~km}$ from each other (Fig. 2, bottom right), the differences observed in their recordings cannot be attributed to differences in epicentral distance or regional attenuation factors, but to site effects.

On October 30, 2016, about 1 month after the installation of the sensors, the Mw 6.5 Norcia earthquake occurred in the central Apennines in Italy. It was followed by several aftershocks of lower magnitude. Nevertheless, we focus on the mainshock waveform because it was the only one recorded both at PRIMA and the accelerometers with a good signalto-noise ratio (larger than 5). CALF and TURF, two broadband stations installed on rock, provide references with no site effects. We choose them in the east and the west part of the region in order to be sure that the epicentral distance difference is not the main reason for the waveform differences. We timedifferentiate the signal of PRIMA, CALF and TURF in order to compare them with the accelerograms of the RAP-RESIF network.

The recorded signals show (Fig. 3) that ground acceleration recorded at PRIMA is clearly the highest. The peak ground acceleration (PGA) is almost four times larger at PRIMA than at NCAU and SLAF, and two times larger than at NCAD. The duration of the signal is also much longer at PRIMA than at the other stations. This earthquake was the 
Table 1

Characteristics of the well-recorded earthquakes at the PRIMA station and used in this study

\begin{tabular}{llllll}
\hline Name & $\begin{array}{l}\text { Date/hour } \\
\text { (UTC) }\end{array}$ & $\begin{array}{l}\text { Latitude/longitude } \\
\text { (degree N and E) }\end{array}$ & Depth $(\mathrm{km})$ & Magnitude & Epicentral distance/PRIMA \\
\hline Chile & $2016-12-2514: 22: 27$ & $-43.84-73.77$ & 33 & Mw $=7.6$ & Teleseismic \\
Solomon & $2017-01-2204: 30: 22$ & -6.24155 .17 & 135 & Mw $=7.9$ & Teleseismic \\
Norcia (Central Italy) & $2016-10-3006: 40: 18$ & 42.8613 .09 & 8 & Mw $=6.5$ & $487 \mathrm{~km}$ \\
Digne (South of France) & $2016-11-1002: 48: 13$ & 44.296 .17 & 4 & Ml $=4$ & $107 \mathrm{~km}$ \\
Limone (Northern Italy) & $2017-04-0809: 52: 34$ & 44.277 .28 & 5 & Ml $=3.6$ & $69 \mathrm{~km}$ \\
Monaco (offshore) & $2018-06-0301: 47: 06$ & 43.637 .72 & 10 & $\mathrm{Ml}=3.1$ & $40 \mathrm{~km}$ \\
\hline
\end{tabular}

Location (stars on Fig. 2), time, and magnitude of the three local events (Digne, Limone and Monaco) were determined by the Géoazur Observatory. For the other events, characteristics are from ISC (International Seismological Center)

first evidence we obtained that clear site effect amplification exists at the PRIMA station.

The recordings on the two broadband stations on rock, CALF and TURF, refer to signals not affected by site effects. The amplitude level that is observed before the $\mathrm{P}$ wave arrival (before $30 \mathrm{~s}$ on the seismograms of Fig. 3) indicates that the level of high-frequency noise is high for this event for the three accelerometric stations SLAF, NCAD and NCAU, whereas it is much lower at PRIMA.

Since the Norcia event of 2016, three local earthquakes have also been very well recorded by PRIMA (stars on Fig. 1, Table 1). The first occurred $107 \mathrm{~km}$ to the northwest (local magnitude, $\mathrm{Ml}=4$, $30 / 10 / 2016$ ), the second one $70 \mathrm{~km}$ to the northeast $(\mathrm{Ml}=3.6,8 / 04 / 2017)$ and the last one, $40 \mathrm{~km}$ to the southeast, occurred offshore Monaco (Ml = 3.1, 3/06/ 2018). As for the Norcia event, we compare the ground motions recorded at the different stations.

We plot the recordings from two earthquakes at the same stations as for the Norcia event (see the Digne event and the Monaco event on Fig. 4). The amplitude (Fig. 4, left) at PRIMA is higher than for the three other nearby stations (NCAU, NCAD, SLAF) but the difference is less clear than the results previously obtained for the Norcia event (Fig. 3). Because the Norcia event occurred $500 \mathrm{~km}$ away, its waveforms were naturally low-pass filtered. We then low-pass filter the waveforms of the local earthquakes (Fig. 4, right, low-pass filter of $2 \mathrm{~Hz}$ ) and we retrieve a larger amplification at PRIMA station and a much longer duration of the signal. This indicates that the amplification of the signal at PRIMA (and to a lower extent at NCAD also) is particularly higher for frequencies below $2 \mathrm{~Hz}$.
In order to better visualize the signal at different frequencies, we plot the S-transforms (Stockwell et al. 1996) of the signals in velocity at stations PRIMA, NCAD and NCAU. Figure 5 shows the spectrogram for the Digne earthquake, but a similar plot could be obtained for the other events. First, the velocity spectral amplitude, represented by colors, is clearly higher at PRIMA than at NCAD, and much higher than NCAU. This is especially clear after the arrival of $\mathrm{S}$ and surface waves (at $20 \mathrm{~s}$ on the horizontal axes). Second, the amplitude is still high after $60 \mathrm{~s}$ at PRIMA, especially at frequencies around $1 \mathrm{~Hz}$ when, on the contrary, the signal at station NCAU and NCAD had already retrieved the level of noise. This increase of the seismic wave's duration is particularly well highlighted by this representation. The frequency band in which the signal is the highest (red colors) is $0.7-10 \mathrm{~Hz}$ for PRIMA, $1-10 \mathrm{~Hz}$ for $\mathrm{NCAD}$, and much narrower at NCAU $(2-8 \mathrm{~Hz})$. On the vertical component of station PRIMA (Fig. 5, top right), we see a strong amplitude at frequencies around $0.1-0.2 \mathrm{~Hz}$. This value, typically observed for offshore seismometers, is well known to be due to sea wave action (Ardhuin et al. 2011; Frontera et al. 2010).

\section{Spectral Analysis on Earthquake Recordings and Ambient Vibrations}

In order to better characterize the site effects at the PRIMA station, we use standard techniques based on spectral ratios, usually applied to inland stations. 
Horizontal EW component, No Filter

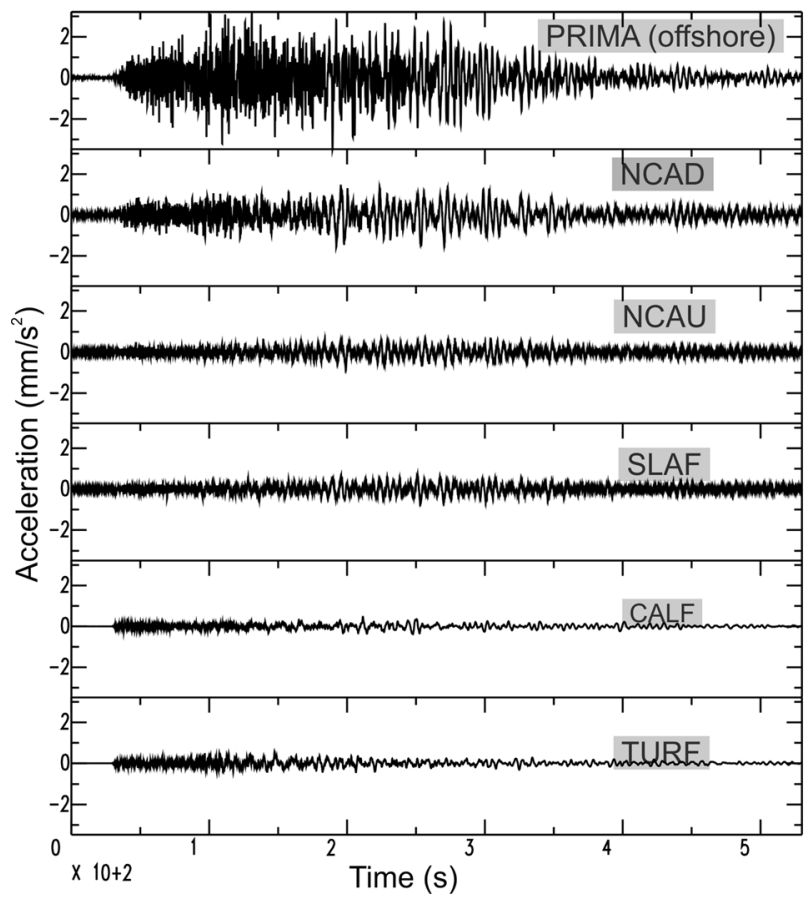

Horizontal NS component, No Filter

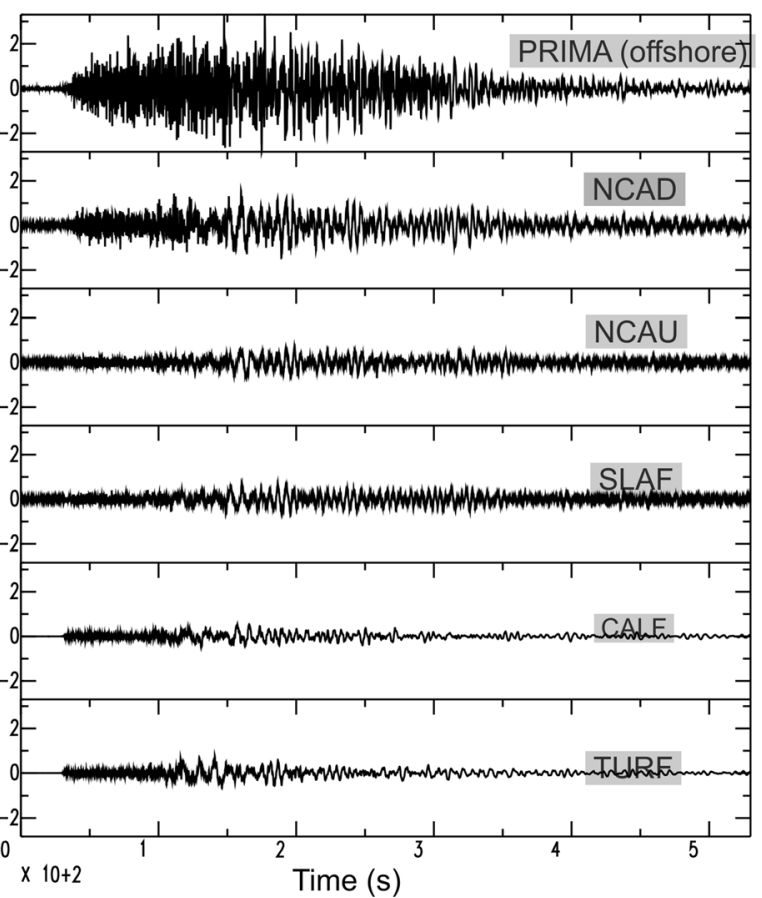

Figure 3

Norcia earthquake (Mw 6.5, Central Italy) on horizontal components of station PRIMA (offshore), stations NCAD, NCAU and SLAF situated less than $3 \mathrm{~km}$ from PRIMA, and broadband stations TURF and CALF. Signals are aligned on the P wave arrival

\subsection{Earthquake Analysis}

The Standard Spectral Ratio (SSR) method allows an estimation of the seismic transfer function by calculating the spectral ratio of seismic records at the site of interest and a reference site, assumed to be free from site effects (Borcherdt and Gibbs 1976). The SSR method imposes that the distance between the studied station and the reference station is small compared to the distance between the hypocenter and the reference station, such that the effects of source and propagation are identical between stations. Then, under the assumption that the signal recorded at the reference station effectively corresponds to the ground motion on the bedrock, the spectral ratio represents the transfer function of the soil column underneath the site.

The first step is then to select a reference station, i.e. a station where the signal is supposed not to be modified by superficial layers or topography, and which simply reflects the incoming wave. In some regions, this selection is particularly difficult (e.g., St
Fleur et al. 2016; Laurendeau et al. 2017). In the present case, stations CALF or TURF would be perfect reference stations in that they are installed on hard rock and we know that they are not affected by site effects. The problem is that these stations are not close enough to PRIMA and the differences obtained in the waveforms are biased by the differences in epicentral distances. We then decide to select the closest station that can be used for comparison: the NCAU station. It is situated on the left side of the Var valley on consolidated conglomerates (a more detailed description of the geological context is given later in this paper).

The second step is to compute spectral ratios for local and regional events. After removing the mean, correcting for instrumental response, tapering and filtering between 0.1 and $15 \mathrm{~Hz}$ to keep a good signal to noise ratio, we apply a fast Fourier transformation and divide the amplitude of the spectra of PRIMA by that of NCAU for each earthquake. We add a small value to the denominator $(1 \%$ of the maximum 
Digne 2016 earthquake $M=4$, dist $=100 \mathrm{~km}$
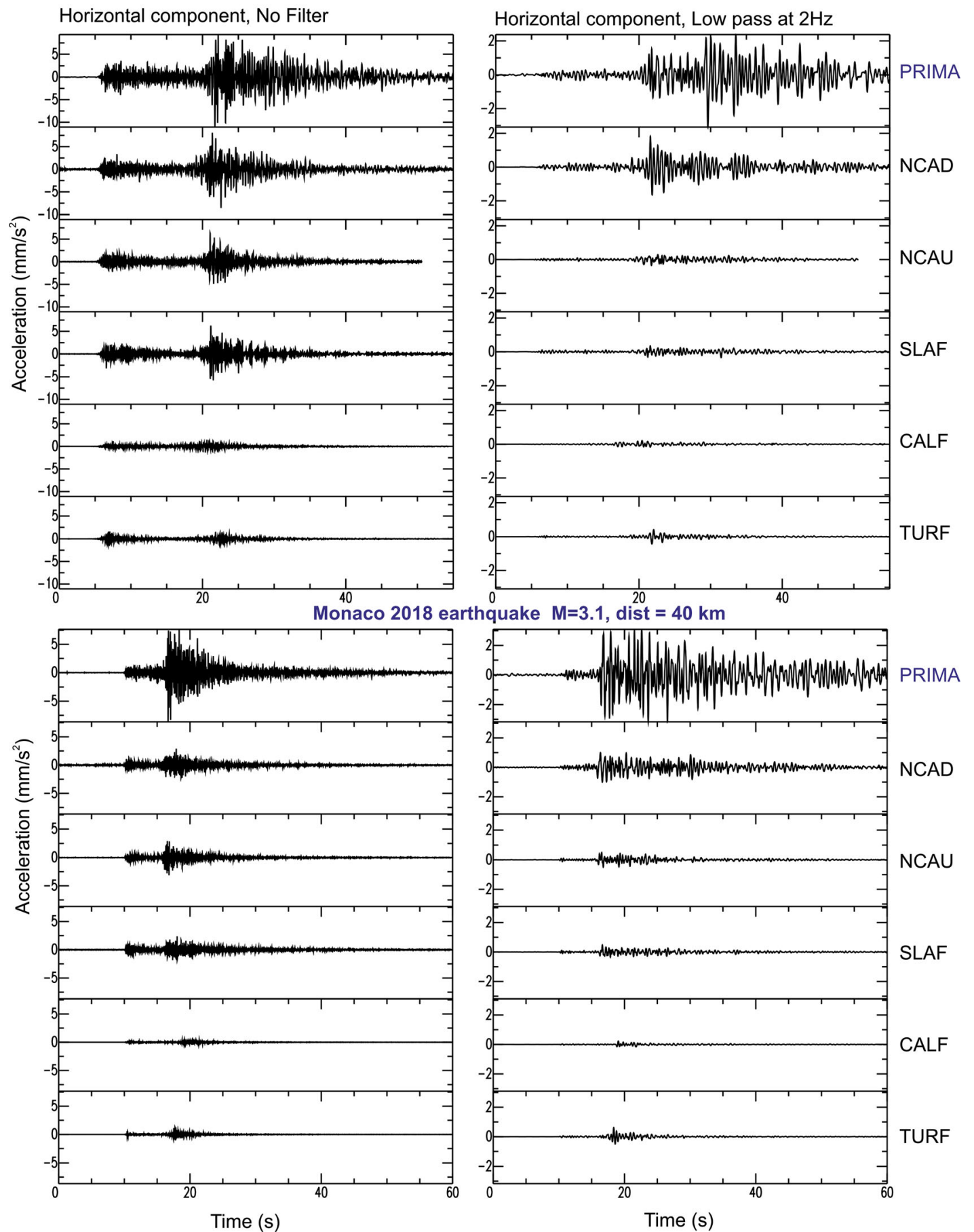

thquake $M=3.1$, dist $=40 \mathrm{~km}$

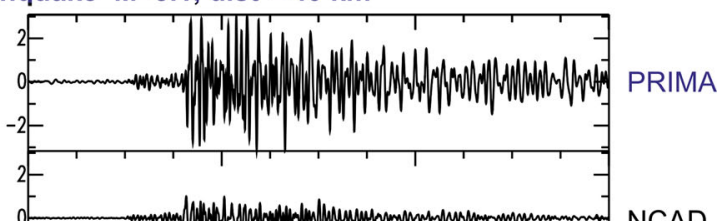

NCAD

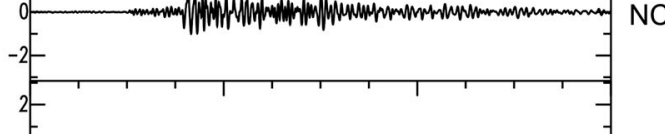

NCAU

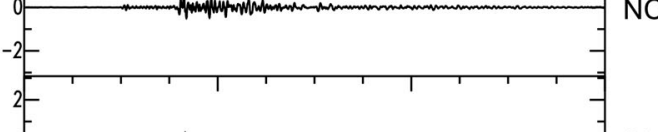

SLAF

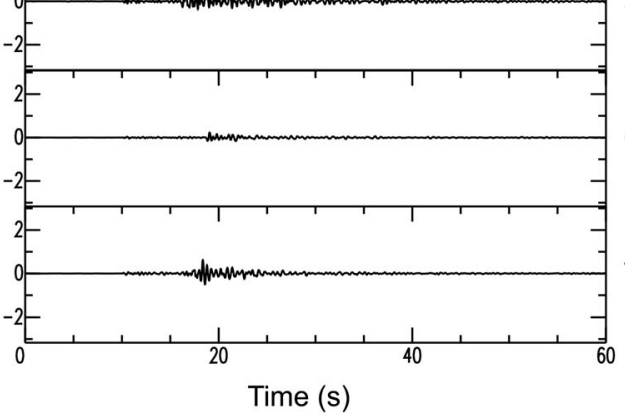

CALF

TURF

Figure 4

Accelerograms (east-west components) of the Digne (Ml 4) and Monaco (Ml 3.1) earthquakes at 6 seismological stations: PRIMA (offshore), NCAD, NCAU and SLAF situated at a maximum of $3 \mathrm{~km}$ from PRIMA in and around the Var valley, and two broadband stations, TURF and CALF, situated on hard rock in the east and the west part of the department (see Fig. 2). Left: unfiltered signals. Right: signals have been lowpass filtered under $2 \mathrm{~Hz}$ (Butterworth filter, 4 poles, 2 pass). Signals are aligned on the $\mathrm{P}$ wave arrival. The amplification at PRIMA is strong, especially for frequencies lower than $2 \mathrm{~Hz}$ 

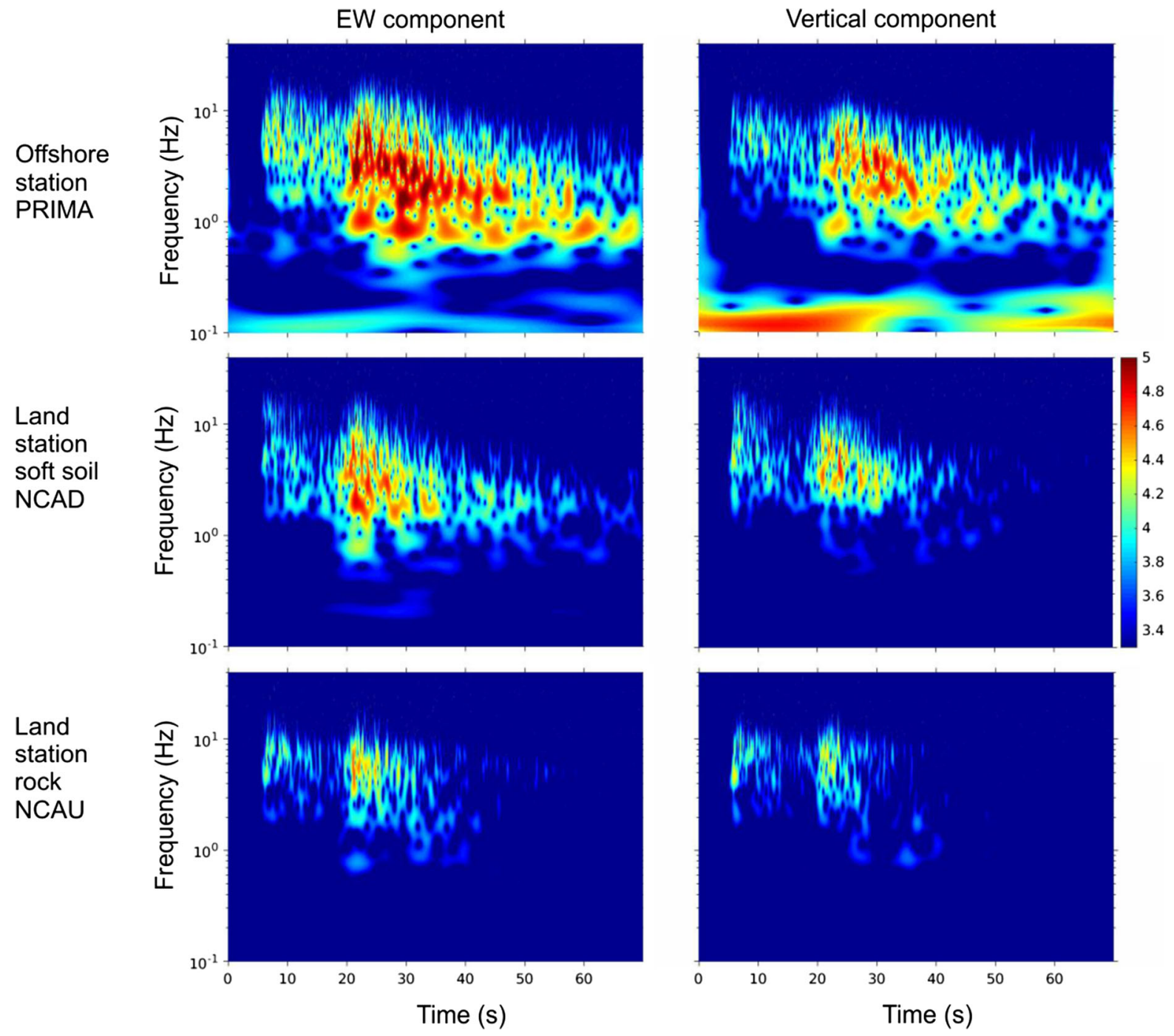

Figure 5

Spectrograms (S-Transforms) of the Digne (Ml 4) local earthquake at station PRIMA (offshore), NCAD in the center of the Var valley and NCAU situated on rock (EW component to the left and the vertical component at right. The signal of NCAD and NCAU have been integrated to be compared with the one at PRIMA). The signals are clearly stronger and longer at station PRIMA than at NCAD and even more NCAU

spectral value) to avoid excessively low values of the frequencies in the spectral division. The spectra are smoothed using a 5-point moving average. We present the results for EW components only because the NS component of the PRIMA sensor was out of order during the Digne and Limone earthquakes (it was later repaired, enabling it to correctly record the last Monaco earthquake).

For the four earthquakes, a first peak appears at a frequency around $0.9 \mathrm{~Hz}(0.7-1.1 \mathrm{~Hz}$, Fig. 6). It reaches high values, larger than 10. A second peak (on Fig. 6) is also visible on the four signals around $1.8 \mathrm{~Hz}$. Its amplitude is very strong for the signal of Digne and Monaco, smaller for Limone and even smaller for the Norcia event. At frequencies around 3-4 Hz, a third peak of amplification can be identified mainly on the signals of the three local earthquakes.

The inter-event variability of spectral ratios is widely observed (e.g. Field and Jacob 1995; St Fleur 


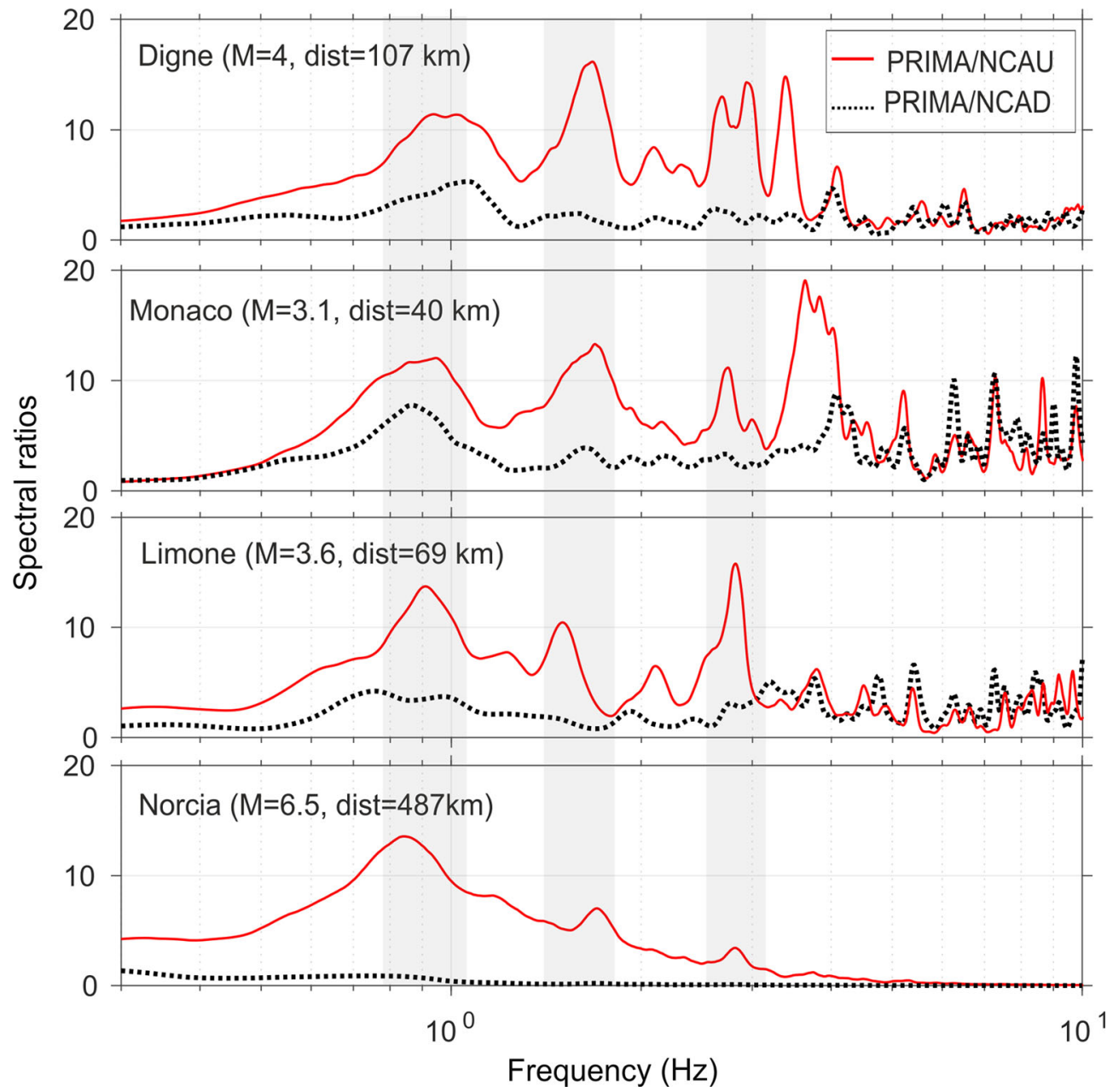

Figure 6

Standard Spectra Ratio (EW components) for the recordings of three local (Digne, Monaco and Limone) and one regional earthquake (Norcia events). The continuous lines represent the spectral ratios between PRIMA and NCAU (left side of the Var valley). Shadow zones underline the main frequencies where amplifications are detected around 0.9, 1.8 and 3-4 Hz. Dotted lines represent the spectral ratio between PRIMA and NCAD (center part of the Var valley) only for the local earthquakes

et al. 2016). It may be due to differences in the azimuth of the incident waves that may interact differently with the geometry of the upper layer interfaces. Unfortunately, in this study, given the small number of available events, it is impossible to correctly analyze these azimuthal effects. The spectral ratio is also restricted to the frequency content of the incoming waves, which mainly depends on the magnitude of the earthquake and the epicentral distance. For the Norcia recordings, for example (Fig. 6, bottom trace), as previously mentioned, the high-frequency content has been naturally removed by the attenuation effect. For this reason the peaks in Fig. 6 are not well expressed at frequencies larger than $2 \mathrm{~Hz}$. This is clear for the regional Norcia event where only those frequencies lower than $3 \mathrm{~Hz}$ have a signal-to-noise ratio higher than 5 (Fig. 6).

\subsection{Ambient Noise Analysis}

We analyze 3 days of ambient seismic noise recordings in order to calculate the spectral ratio between horizontal and vertical components at the PRIMA station. The so-called $\mathrm{H} / \mathrm{V}$ method (or 

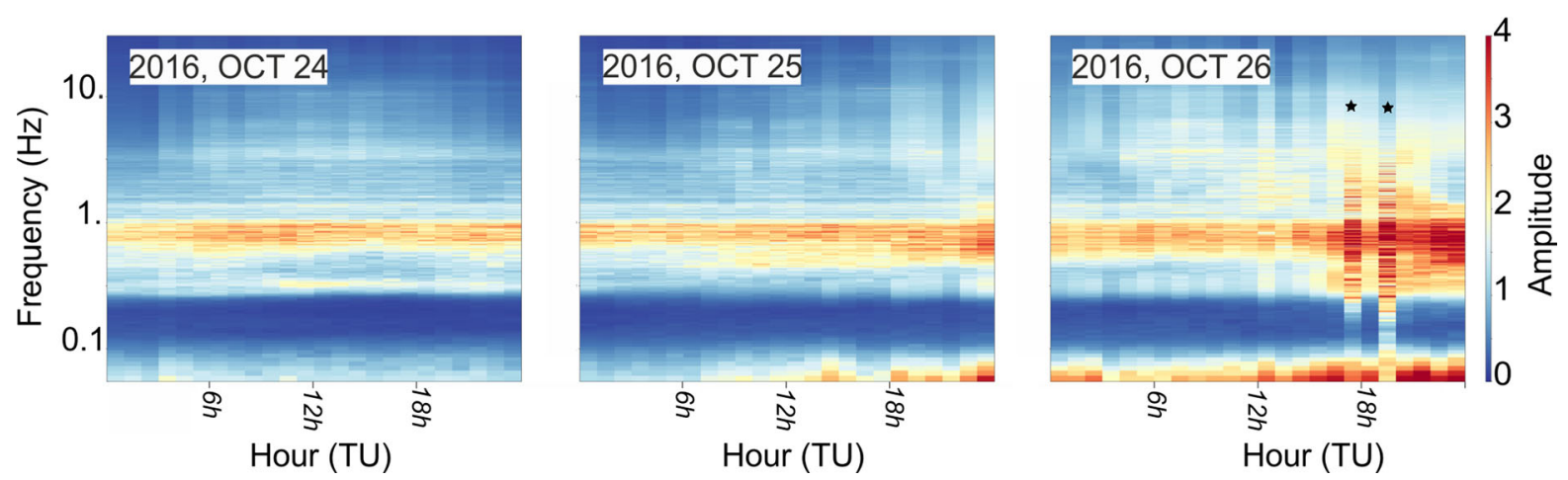

Figure 7

H/V spectral ratios over 3 days of ambient vibrations at the PRIMA station. The main frequency peak around $0.7-1 \mathrm{~Hz}$ is clear all along the time period. Black stars indicates the hour of two earthquakes from Central Italy $(17: 10, \mathrm{Mw}=5.5$ and $19: 18$, Mw $=6.1$. distance $\sim 500 \mathrm{~km}$ )

HVSR) is widely used to obtain the main frequencies that are amplified at a given site (Nakamura 1989). The method is particularly useful when a main impedance contrast exists in a 1D layered underground medium.

After mean removal, tapering and bandpass filtering between 0.02 and $20 \mathrm{~Hz}$, we calculate the $\mathrm{H} / \mathrm{V}$ ratios by a moving window of $1 \mathrm{~h}$ of time duration. The horizontal signal, $\mathrm{H}$, is taken as the quadratic mean of both horizontal components. In Fig. 7, the time dependent $\mathrm{H} / \mathrm{V}$ ratios can be seen for the 3-day period from October 24 to October 26, 2016. A main frequency peak around $0.7-1 \mathrm{~Hz}$ can be clearly seen all along the time period, which is surely related to the resonance of the sedimentary sequence of the slope. The mean value of this frequency is constant but the variability around this value is wider at some moments. This variability is not related to days and night (therefore not linked to aircraft activity). At lower frequencies, between 0.1 and $0.2 \mathrm{~Hz}$, an extremely low $\mathrm{H} / \mathrm{V}$ value (lower than one) is obtained. This is certainly due to the fact that the vertical component (denominator in the $\mathrm{H} / \mathrm{V}$ ratio) at this frequency is high and dominated by the action of the swell (as previously seen on the spectrograms of Fig. 5). On the third day (October 26), we can detect the occurrence of two earthquakes (Central Italy at 17:10, moment magnitude, $\mathrm{Mw}=$ 5.5 and 19:18, $\mathrm{Mw}=6.1$, distance $=500 \mathrm{~km}$ ). The $\mathrm{H} / \mathrm{V}$ variations when the seismic waves arrive, as well as the influence of weather conditions will be further analyzed in future research work.
If we compare the $\mathrm{H} / \mathrm{V}$ results for ambient seismic noise with the SSR results for earthquake data (Fig. 6), we remark a good coherency of the main peak around $0.9 \mathrm{~Hz}$. Nevertheless, the peaks that are obtained at higher frequencies on SSR between 1.5 and $4 \mathrm{~Hz}$ are not clearly expressed in the $\mathrm{H} / \mathrm{V}$ ratios from ambient noise.

\section{Interpretation and Discussion}

In this section we present geological and geophysical constraints that bring new elements to explain the seismological observations.

\subsection{Geological Constraints}

We build two geological cross sections in the lower Var valley, one along strike the valley (Fig. 8c) and the other one perpendicular to it, (Fig. 8b. See Fig. 8a for an aerial view of the profile and the station location) in order to image the depth of the major interfaces. These cross-sections are based on the interpolation of data from (1) several boreholes (down to 100-m-depth), including one 70-m-depth located near the NCAD station (Dubar and Anthony 1995); (2) onshore and offshore field data on the Pliocene conglomerates (Clauzon 1978; Piper and Savoye 1993) and (3) local Electrical Resistivity Measurements (ERM) (Guglielmi 1993) and (4) one older seismic reflection profile that helped us to 


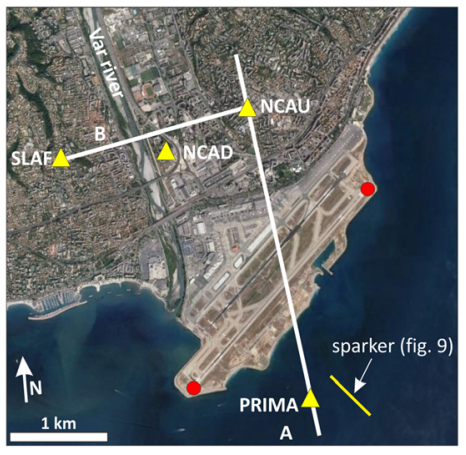

(a)

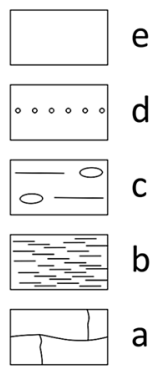

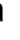

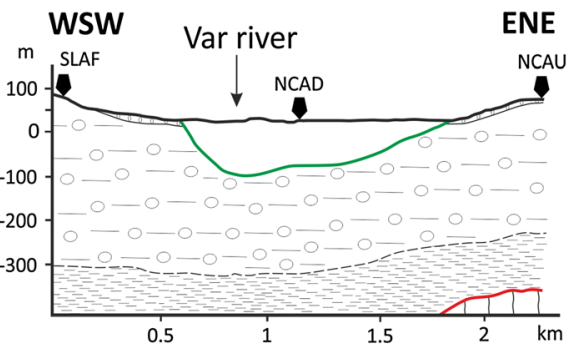

(b)

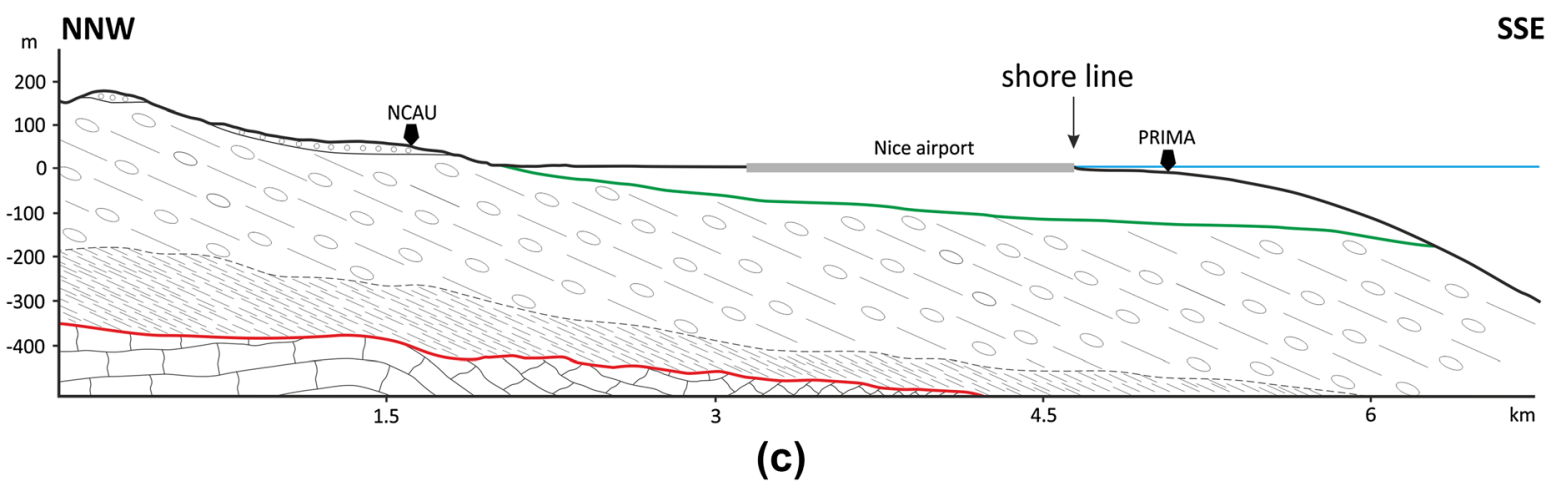

Figure 8

a Aerial view of the studied area. SLAF, NCAD, NCAU and PRIMA stations are represented by yellow triangles and the geological crosssections by white lines. The two red dots on the airport platform correspond to the 100-m-deep boreholes used in this work (BSS002HJFT to the west and BSS002HJFR to the East, http://infoterre.brgm.fr/). The yellow line offshore represents the position of the sparker profile presented in Fig. 9. On the two cross sections $\mathbf{b}$ and $\mathbf{c}$, green lines represent the limit between the Holocene sedimentary cover and the Pliocene conglomerates. It is this limit that is responsible for large wave amplification along the Var Valley and PRIMA station. Red lines indicate the Jurassic limestones depth. Description of the geological layers: a Jurassic limestones, b and c: Pliocene-Early Pleistocene Var Gilbert delta deposits (marls and conglomerates respectively), d Late Pleistocene alluvial terraces, e Holocene Var delta deposits (sand and gravels)

image the top of the Jurassic limestone (Horn et al. 1965).

At the surface, a few meters of alluvial terraces of Pleistocene age cover the eastern and western slopes of the lower Var valley (Fig. 8b). Stations NCAU and SLAF are located on the hills of Nice, made of the Pliocene conglomerates while NCAD and PRIMA are located in the lower Var valley on Holocene sands and gravels. Onshore, NCAD lies on a nearly horizontal topography, while offshore, PRIMA is at the boundary with the upper continental slope dipping $20^{\circ}$ southward.

The central part of the lower Var valley is filled by fine-grained shallow marine and estuarine-deltaic sediments dating from the Holocene, which have accumulated during the last $10 \mathrm{ky}$ in this small deep and narrow valley (white layer under stations NCAD and PRIMA in Fig. 8b and c). Below, the Pliocene deposits of the Var Gilbert delta (marine marls and coarse conglomerates) lie on the Jurassic limestones. The contact between these two geological formations is the Messinian erosional surface (Clauzon 1978; Lofi et al. 2011). At depth, the boreholes enable us to characterize the sedimentology of the first hundred meters below the topographic surface. The ERM, seismic reflection profile and field data enable us to assess the depth of the Holocene sands-Pliocene conglomerates and the Jurassic limestones/Pliocene marls-conglomerate boundary (red line in Fig. 8c).

The Holocene and Pliocene deltaic formations display highly variable thicknesses and a particular pinch-out geometry related to the progradation of the 


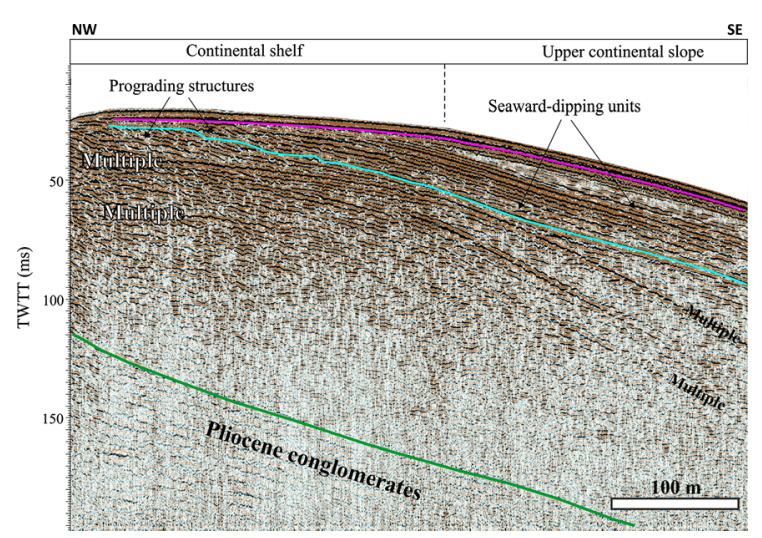

Figure 9

Sparker profile (location on Figs. 1 and 8). The seafloor corresponds to the pink reflector. As in Fig. 8, the green reflector is the boundary between the Pliocene Var conglomerates and the Holocene deposits. Prograding sedimentary structures are underlined by the blue reflector

deltaic sedimentation. At shallow depth, the highest velocity contrast is located at the boundary between the Var conglomerates (Pliocene) and the Holocene deposits.

\subsection{Offshore Seismic Profile}

High-resolution seismic profiles (Sparker profile) were collected close to PRIMA station (see location on the map of Fig. 8a) using a SIG2mille energy source coupled with a single-channel streamer 50-m long during the Sparklice campaign (2014). The profile was shot using an energy of $250 \mathrm{~J}$, at a speed of 4 knots. With such a configuration, it is possible to penetrate up to 100-150 ms below the seafloor with a theoretical vertical resolution of $0.5-1 \mathrm{~m}$. Raw data were corrected from the wave effect before geological interpretation. The profile shown in the paper enables to discriminate several shallow seismic units (Fig. 9). At depth, a well-layered, low-frequency and low-amplitude reflection unit is observed. It is located below the seafloor at a depth increasing from about $90 \mathrm{~ms}$ (corresponding to a depth of $67-76 \mathrm{~m}$, the uncertainty is due to the uncertainty in the $\mathrm{Vp}$ value, from $1500-1700 \mathrm{~m} / \mathrm{s}$ in the sea, used for the conversion) to $140 \mathrm{~ms}(105-119 \mathrm{~m})$ going seaward (green line on Fig. 9). Its upper contact exhibits a mean slope of $4.4^{\circ}$ to the south. This boundary represents the top of the Pliocene conglomerates that has been identified on the geological profiles (green line on Fig. $8 \mathrm{~b}$ and c). In the northern part of the profile, between 110 and $40 \mathrm{~ms}$ below the seafloor, the acoustic signal is disrupted by the multiples, thus information about the sediment architecture can be obtained only in the shallowest interval, 20-50 ms below the seafloor (about $15-40 \mathrm{~m}$ ). On the continental shelf, prograding structures with moderate to high-amplitude reflections are present and can be interpreted as coarser-grained shallow delta deposits. Around the transition between the continental shelf and the upper slope, prograding structures change into continuous and parallel moderate to high-amplitude reflections dipping seaward (blue line on Fig. 9).

These shallow structures reveal that a significant thickness of recent sediment has deposited in this area, and seaward prograding structures make this sedimentary accumulation particularly prone to landslide.

\subsection{Discussion}

Our analysis suggests that the strong amplification observed at the PRIMA station at low frequency ( $\mathrm{f}=0.9 \mathrm{~Hz}$ ) is certainly related to the limit between the conglomerate and the soft quaternary sediment underlined by the green line on the geological profiles (Fig. 8) at an approximate depth of 90-120 m. Indeed, if the deeper interface between Jurassic limestones and Pliocene deposits (red line on Fig. 8) was in cause, it would also affect station NCAU and SLAF, which is not the case.

The average shear wave velocity in the sediment of the lower Var valley has been determined by independent in situ experiments by the CEREMA group (Rohmer et al. 2019) at around $400 \mathrm{~m} / \mathrm{s}$. If we use the simple 1D formula to retrieve the resonance frequency of a layer $\mathrm{fO}=\mathrm{Vs} / 4 \mathrm{H}$, where $\mathrm{H}$ is the interface depth and Vs the shear-wave velocity, we find that the resonance frequency should be between $0.8 \mathrm{~Hz}$ (for $\mathrm{H}=120 \mathrm{~m}$ ) and $1.1 \mathrm{~Hz}$ (for $\mathrm{H}=90 \mathrm{~m}$ ). This is coherent with the first frequency pick we obtain on SSR around $0.9 \mathrm{~Hz}$, and then confirms that it is this interface that plays a major role in the amplification obtained at low frequency. This also explains why this low frequency amplification no 
longer exists at SLAF and NCAU, which are situated on the sides of the valley (Figs. 4, 8b).

Thus, both PRIMA and NCAD being situated in the central part of the Var valley, we could expect that they amplify seismic waves identically. Nevertheless, after looking at time domain seismograms (Fig. 4) it is clear that for frequencies lower than $2 \mathrm{~Hz}$ the wave amplitudes are higher at PRIMA than at NCAD. In order to evaluate the differences between both stations, we divide the Fourier spectra of PRIMA recordings by those of NCAD (dotted black lines of Fig. 6). For the first frequency peak $(0.9 \mathrm{~Hz})$, the relative amplification between PRIMA and NCAD remains, but is strongly attenuated (we obtain values of 3-7, when the spectral ratio using NCAU reached 10-15). This means that at PRIMA, a specific effect causes the increase of the signal amplitude and duration at this frequency.

Because PRIMA is an offshore station, it is important to understand the effect of the water layer on the recordings. Boore and Smith (1999) analyzed the recordings of eight earthquakes at six offshore sites and found that the $\mathrm{P}$ waves could be modified mainly for a resonant frequency $f p=V p / 4 h w$, where $\mathrm{Vp}$ is the $\mathrm{P}$ wave velocity in the sea and hw the water depth ( $\mathrm{S}$ waves are not affected by the water layer). In our case, $\mathrm{hw}=18 \mathrm{~m}$ and if we take $\mathrm{Vp}=1500 \mathrm{~m} / \mathrm{s}$, we obtain a main resonance at $21 \mathrm{~Hz}$, which is beyond the frequency range studied here.

Another reason must then be found to explain the differences obtained at NCAD and PRIMA. One solution could be a $2 \mathrm{D}-3 \mathrm{D}$ effect due to the special pinch-out geometry related to the termination of the Holocene sedimentary layer in the PRIMA area (Fig. 8c). This effect could enhance surface wave generation and thus the duration and amplitude of seismograms, as has been observed in other regions (Cruz-Atienza et al. 2016).

To check this hypothesis, we ran several simulations using the SPECFEM2D 7.0.0 (Tromp et al. 2008; Komatitsch et al. 2012) published under the CECILL V2 license, using the transverse geological cross-section passing through PRIMA and NCAU stations (Fig. 8c). The physical model is discretized in two linear elastic subdomains: the conglomerate bedrock with compressional velocity $\mathrm{Vp}=2500 \mathrm{~m} / \mathrm{s}$, shear wave velocity Vs $=1200 \mathrm{~m} / \mathrm{s}$, and density rho $=2200 \mathrm{~kg} / \mathrm{m}^{3}$, a single sedimentary layer of $\mathrm{Vp}=1600 \mathrm{~m} / \mathrm{s}, \mathrm{Vs}=450 \mathrm{~m} / \mathrm{s}$ and rho $=2000 \mathrm{~kg} /$ $\mathrm{m}^{3}$, which corresponds to the alluvial infill of the Var valley, and one linear acoustic subdomain corresponding to the water layer with compressional wave velocity $\mathrm{Vp}=1500 \mathrm{~m} / \mathrm{s}$ and water density rho = $1000 \mathrm{~kg} / \mathrm{m}^{3}$. These characteristics are taken from the recent study of Rohmer et al. (2019). The unstructured numerical mesh contains 11,506 quadrilateral elements and allows simulations up to $5 \mathrm{~Hz}$ maximum frequency. Snapshots of the incoming plane wave with SV polarization can be seen at different $\mathrm{t}=0,2,4$ and $6 \mathrm{~s}$ (Fig. 10). The incoming SV plane wave is modulated in time by a Ricker source time function with $1 \mathrm{~Hz}$ central frequency (usable frequency band between 0.2 and $2.5 \mathrm{~Hz}$ ). We placed receivers on top of the solid subdomain from the onshore to the offshore sides in order to compare the variation of seismic wave amplification with respect to the first receiver (REF on Fig. 10) which corresponds to the location of the NCAU station $(\mathrm{X}=725 \mathrm{~m})$. The offshore receiver chosen to simulate the PRIMA seismograms is located at $\mathrm{X}=5000 \mathrm{~m}$, around $18 \mathrm{~m}$ water depth. A third virtual station is located inland on the sedimentary layers of the Var valley (VAR on Fig. 10). The simulated seismograms on the three virtual stations along the profile are presented (Fig. 10, right side) for vertical and horizontal components. For the vertical components, we obtained that the signal on PRIMA has an amplitude 3 times larger than on VAR and 5 times larger than on REF. It is interesting also to note the time elongation of the synthetic signals near the pinch-out tip on the sea side, certainly due to the converted waves in the sedimentary layer. On the horizontal traces, we were unable to reproduce the large amplification observed at PRIMA. We ran additional simulations varying the incoming polarization angle of the SV plane-wave obtaining similar results (maximum amplifications up to 5, mainly on the vertical components) but we could not succeed in reproducing the data. This model is thus too simple to reproduce the large amplification measured. As a next step, we plan to implement fully 3D simulations in a larger frequency band, which aim to better explain the offshore site effect and its larger amplitude with respect to the inland stations. 

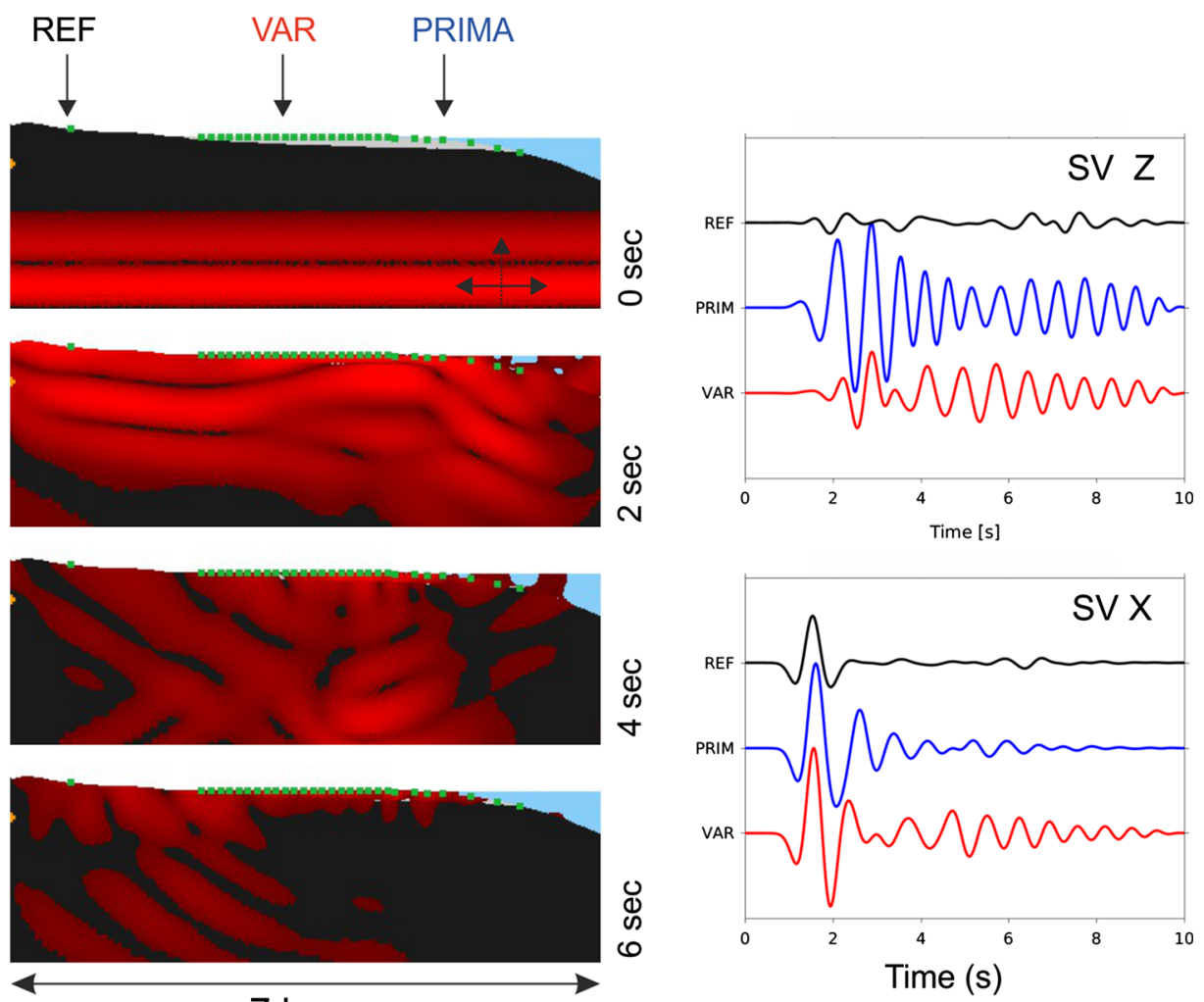

$7 \mathrm{~km}$

Figure 10

Left: snapshots of the displacement field in red (vector moduli) at different simulation times. At $0 \mathrm{~s}$ the incident horizontal SV input wave, at $2 \mathrm{~s}$ the reflected wavefield at the surface begins to interact with the incoming and the converted waves in the sedimentary layer. At $4 \mathrm{~s}$ and $6 \mathrm{~s}$ the surface wave train is already formed and can be clearly seen in the sedimentary layer, emitting some body waves at both sides of the sedimentary layer tips. The size of the simulation domain is $7000 \mathrm{~m}$ length by $2000 \mathrm{~m}$ height. The elastic bedrock subdomain is shown in black, the sedimentary layer is shown in gray and the water layer in light blue. The green dots represent receiver positions. The reference station (REF), a station on the top of the sedimentary layers of the Var valley (VAR), and offshore station (PRIMA) are shown by vertical arrows. Right: synthetic seismograms of the displacement field at the three virtual stations REF, VAR and PRIMA on the vertical (top) and the horizontal components (bottom)

Concerning the second and third peaks observed in the SSR (1.8 and 3-4 Hz on Fig. 6) the amplifications are similar for NCAD and PRIMA with respect to NCAU (the dotted line is around one in Fig. 6). We then conclude that they may be due to the sedimentary layered structures present all along the lower Var valley.

For frequencies higher than $5 \mathrm{~Hz}$, the amplification only exists at PRIMA (it persists if PRIMA is divided by NCAD, Fig. 6). This high-frequency amplification could be due to shallower layers: prograding structures visible on the sparker image or even the $2-4 \mathrm{~m}$ of unconsolidated mud present in the area (Sultan et al. 2004).
For many years, site effects have been studied in the city of Nice from the measurement of earthquakes, ambient vibration and numerical modelization (Courboulex et al. 2001; Duval and Vidal 2003; Semblat et al. 2000, 2008). Duval et al. (2013) summarized the results obtained by the measurements of $\mathrm{H} / \mathrm{V}$ on ambient vibrations at 687 sites and presented a map of the main resonance frequency. They showed that in alluvial deposit zones, the main resonance frequency is lower than $2 \mathrm{~Hz}$. On the airport runaways inland, they obtained a resonance frequency around $1 \mathrm{~Hz}$, compatible with our offshore results. New PRIMA recordings enabled us to confirm that the site effect exists also under sea water, that the amplification factor is larger than 10 
for $\mathrm{f}=0.9 \mathrm{~Hz}$, and that the signal length is enhanced due to a large generation of surface waves.

To what extent can a site effect be dangerous for airport zone stability? Roesner et al. (2019) recently attempted to answer this question. They thought that the site effect at the airport should be the same as that obtained at a station located on soft sediments west of Nice, the NALS station, (see its location of Fig. 2, top right map). In their study, they considered the signals of a magnitude 6.3 earthquake on a fault $25 \mathrm{~km}$ south of Nice, simulated at this station by Salichon et al. (2010) using an empirical Green's function method that allows a realistic account of site effects. The uniform cyclic triaxial tests they used indicate that using this input motion (with a PGA around $0.5 \mathrm{~ms}^{-1}$ ), liquefaction failure is likely to occur in Nice slope sediments. They highlight that a potential future submarine landslide could have a slide volume similar to the 1979 event.

Thanks to the results presented in this paper, we now know that the linear amplification due to site effects is strong on the airport slope, especially at frequencies around $0.8-1 \mathrm{~Hz}$. This amplification should be taken into account to quantify how it increases the triggering power of a future earthquake in the area. In the case of strong shaking, non-linear effects that may reduce high-frequency values and increase lower frequencies (Bonilla et al. 2011; Régnier et al. 2016) should also be taken into account.

\section{Conclusion}

Thanks to the analysis of seismic recordings at a new broadband offshore station, we find a large amplification of the seismic waves on the outer shelf offshore Nice airport. The sparker image reveals a significant thickness of recent sediments and seaward prograding structures that makes this zone prone to landslides. The site amplification we have highlighted increases the amplitude of the incoming seismic waves and thus the probability of triggered landslide during a future earthquake.

This offshore site effect is probably also strong in many other regions of the world and thus should be considered in submarine shaking-triggered slopestability failure studies. Site effects are increasingly taken into account in the hazard prevention plans through the use of microzonation results in building codes. Since offshore constructions are becoming frequent, it is important that this effect is also taken into account at sea.

\section{Acknowledgements}

We thank David Ambrois and Jenny Trévisan for their help, Maëlle Kelner for her careful reading and commentaries, as well as Etienne Bertrand, Ophélie Rohmer and Michel Dubar for fruitful discussions. We thank the EMSO-Nice Observatory, who made the PRIMA data available, and the seismological observatory of Geoazur laboratory, who maintain the permanent RESIF network in the area. Seismological data are from the RESIF network, which is a national Research Infrastructure, recognized as such by the French Ministry of Higher Education and Research. RESIF is managed by the RESIF Consortium, composed of 18 research institutions and universities in France. RESIF is additionally supported by a public grant overseen by the French National Research Agency (ANR) as part of the "Investissements d'Avenir" program (reference: ANR11-EQPX-0040) and the French Ministry of Ecology, Sustainable Development and Energy. All the seismograms and station characteristics used in this study can be downloaded on RESIF portal http://dx.doi.org/10. 15778/RESIF.FR and http://dx.doi.org/10.15778/ RESIF.RA. This work has been supported by the French government, through the UCA-JEDI Investments in the Future project under reference number ANR-15-IDEX-01. It is also part of the ANR Modal project 17-CE01-0017 managed by IFREMER (N. Sultan).

Open Access This article is licensed under a Creative Commons Attribution 4.0 International License, which permits use, sharing, adaptation, distribution and reproduction in any medium or format, as long as you give appropriate credit to the original author(s) and the source, provide a link to the Creative Commons licence, and indicate if changes were made. The images or other third party material in this article are included in the article's Creative Commons licence, unless indicated otherwise in a credit line to the material. If material is not included in the article's Creative Commons licence and your intended use is not permitted by statutory regulation or exceeds the permitted use, you will need to obtain permission directly from the copyright holder. To view a 
copy of this licence, visit http://creativecommons.org/licenses/by/4. $0 /$.

\section{Publisher's Note Springer Nature remains neutral} with regard to jurisdictional claims in published maps and institutional affiliations.

\section{REFERENCES}

Ai, F., Förster, A., Stegmann, S., \& Kopf, A. (2014). Geotechnical characteristics and slope stability analysis on the deeper slope of the Ligurian margin, Southern France. In K. Sassa, P. Canuti, \& Y. Yin (Eds.), Landslide science for a safer geoenvironment (pp. 549-555). https://doi.org/10.1007/978-3-319-04996-0_84.

Anderson, J. G., Bodin, P., Brune, J. N., Prince, J., Singh, S. K., Quaas, R., et al. (1986). Strong ground motion from the Michoacan, Mexico earthquake. Science, 233(4768), 1043-1049.

Ardhuin, F., Stutzmann, E., Schimmel, M., \& Mangeney, A. (2011). Ocean wave sources of seismic noise. Journal of Geophysical Research, 116, C09004. https://doi.org/10.1029/ 2011JC006952.

Bonilla, L. F., Tsuda, K., Pulido, N., Régnier, J., \& Laurendeau, A. (2011). Nonlinear site response evidence of K-NET and KiK-net records from the 2011 off the Pacific coast of Tohoku Earthquake. Earth, Planets and Space, 63(7), 50.

Boore, D. M., \& Smith, C. E. (1999). Analysis of earthquake recordings obtained from the Seafloor Earthquake Measurement System (SEMS) instruments deployed off the coast of southern California. Bulletin of the Seismological Society of America, 89(1), 260-274.

Borcherdt, R. D., \& Gibbs, J. F. (1976). Effects of local geological conditions in the San Francisco Bay region on ground motions and the intensities of the 1906 earthquake. Bulletin of the Seismological Society of America, 66, 467-500.

Cavalié, O., Sladen, A., \& Kelner, M. (2015). Detailed quantification of delta subsidence, compaction and interaction with manmade structures: the case of the NCA airport, France. Natural Hazards and Earth System Sciences, 15, 1973-1984.

Chousianitis, K., Del Gaudio, V., Sabatakakis, N., Kavoura, K., Drakatos, G., Bathrellos, G. D., et al. (2016). Assessment of earthquake-induced landslide hazard in Greece: From arias intensity to spatial distribution of slope resistance demand assessment of earthquake-induced landslide hazard in Greece. Bulletin of the Seismological Society of America, 106(1), 174-188.

Clauzon, G. (1978). The Messinian Var canyon (Provence, Southern France) - paleogeographic implications. Marine Geology, 27(3-4), 231-246.

Clayton, R. W., Heaton, T., Kohler, M., Chandy, M., Guy, R., \& Bunn, J. (2015). Community seismic network: A dense array to sense earthquake strong motion. Seismological Research Letters, 86(5), 1354-1363.

Courboulex, F., Larroque, C., Deschamps, A., Kohrs-Sansorny, C., Gélis, C., Got, J. L., et al. (2007). Seismic hazard on the French Riviera: Observations, interpretations and simulations.
Geophysical Journal International, 170, 387-400. https://doi. org/10.1111/j.1365-246X.2007.03456.x.

Cruz-Atienza, V. M., Tago, J., Sanabria-Gómez, J. D., Chaljub, E., Etienne, V., Virieux, J., et al. (2016). Long duration of ground motion in the paradigmatic valley of Mexico. Scientific Reports, 6, 38807.

Dan, G., Sultan, N., \& Savoye, B. (2007). The 1979 Nice harbour catastrophe revisited: Trigger mechanism inferred from geotechnical measurements and numerical modelling. Marine Geology, 245, 40-64. https://doi.org/10.1016/j.margeo.2007.06. 011.

Dubar, M., \& Anthony, E. J. (1995). Holocene environnemental change and river-mouth sedimentation in the Baie des Anges, French Riviera. Quaternary Research, 43, 329-343.

Duval, A. M., Bertrand, E., Vidal, S. \& Delgado, J. (2013). Détection des effets de site sismiques: Mise au point de méthodes expérimentales et application à Nice. Bulletin du laboratoire de ponts et Chaussées, 279, 3-20.

Duval, A. M., \& Vidal, S. (2003). Contribution à l'étude de l'aléa local à Nice: Complément d'analyse du bruit de fond sismique. Rapport CETE Méditerranée, $\mathrm{n}^{\circ}$ 987400136/04.

Field, E. H., \& Jacob, K. H. (1995). A comparison and test of various site response estimation techniques, including three that are not reference site dependent. Bulletin of the Seismological Society of America, 85(4), 1127-1143.

Frontera, T., Ugalde, A., Olivera, C., Jara, J. A., \& Goula, X. (2010). Seismic ambient noise characterization of a new permanent broadband ocean bottom seismometer site offshore Catalonia (Northeastern Iberian Peninsula). Seismological Research Letters, 81(5), 740-749.

Gennesseaux, M., Mauffret, A., \& Pautot, G. (1980). Les glissements sous-marins de la pente continentale Niçoise et la rupture de câbles en mer Ligure (Mediterranée Occidentale). Comptes Rendus de l'Académie des Sciences, 290, 959-962.

Goldfinger, C., Ikeda, Y., Yeats, R. S., \& Ren, J. (2013). Superquakes and supercycles. Seismological Research Letters, 84, 24-32. https://doi.org/10.1785/0220110135.

Gomberg, J. (2018). Cascadia onshore-offshore site response, submarine sediment mobilization, and earthquake recurrence. Journal of Geophysical Research: Solid Earth, 123(2), 1381-1404.

Guglielmi, Y., (1993). Hydrogéologie des aquifères Plio-Quaternaires de la basse vallée du Var. Ph.D. Thesis, Université d'Avignon et des Pays du Vaucluse, 178 pp.

Hassoun, V., Martin, J., Migeon, S., Larroque, C., Cattaneo, A., Eriksson, M., \& Heimbürger, L. E. (2014). Searching for the record of historical earthquakes, floods and anthropogenic activities in the var sedimentary ridge (NW Mediterranean). In Submarine mass movements and their consequences (pp. 571-581). Cham: Springer. https://doi.org/10.1007/978-3-31900972-8_51.

Horn R., Ménard F. \& Munk F. (1965). Etude géophysique de la basse vallée du Var. Rapport B.R.G.M. DS.65.A 37 (http:// infoterre.brgm.fr/rapports/65-DS-A037.pdf).

Ioualalen, M., Larroque, C., Scotti, O., \& Daubord, C. (2014). Tsunami mapping related to local earthquakes on the FrenchItalian Riviera (Western Mediterranean). Pure and Applied Geophysics, 171(7), 1423-1443.

Ioualalen, M., Migeon, S., \& Sardoux, O. (2010). Landslide tsunami vulnerability in the Ligurian Sea: Case study of the 1979 October 16 Nice international airport submarine landslide and of 
identified geological mass failures. Geophysical Journal International, 181(2), 724-740.

Kawamura, K., Laberg, J. S., \& Kanamatsu, T. (2014). Potential tsunamigenic submarine landslides in active margins. Marine Geology, 356, 44-49.

Kelner, M., Migeon, S., Tric, E., Courboulex, F., Dano, A., Lebourg, T., et al. (2016). Frequency and triggering of smallscale submarine landslides on decadal timescales: Analysis of 4D bathymetric data from the continental slope offshore Nice (France). Marine Geology, 379, 281-297.

Klaucke, I., \& Cochonat, P. (1999). Analysis of past seafloor failures on the continental slope off Nice (SE France). GeoMarine Letters, 19(4), 245-253.

Komatitsch, D., Vilotte, J.-P., Cristini, P., Labarta, J., Le Goff, N., Le Loher, P., Liu, Q., Martin, R., Matzen, R., Morency, C., Peter, D., Tape, C., Tromp, J., \& Xie, Z. (2012). SPECFEM2D v7.0.0 [software], Computational infrastructure for geodynamics. https://geodynamics.org/cig/software/specfem2d/.

Kopf, A. J., Stegmann, S., Garziglia, S., Henry, P., Dennielou, B., Haas, S., et al. (2016). Soft sediment deformation in the shallow submarine slope off Nice (France) as a result of a variably charged Pliocene aquifer and mass wasting processes. Sedimentary Geology, 344, 290-309.

Krijgsman, W., Langereis, C. G., Zachariasse, W. J., Boccaletti, M., Moratti, G., Gelati, R., et al. (1999). Late Neogene evolution of the Taza-Guercif Basin (Rifian Corridor, Morocco) and implications for the Messinian salinity crisis. Marine Geology, 153(1-4), 147-160.

Kubo, H., Nakamura, T., Suzuki, W., Kimura, T., Kunugi, T., Takahashi, N., et al. (2018). Site amplification characteristics at nankai seafloor observation network, DONET1, Japan, evaluated using spectral inversion. Bulletin of the Seismological Society of America, 108(3A), 1210-1218. https://doi.org/10.1785/0120170254.

Larroque, C., Béthoux, N., Calais, E., Courboulex, F., Deschamps, A., Déverchère, J., et al. (2001). Active and recent deformation at the Southern Alps-Ligurian basin junction. Geologie en Mijnbouw, 80, 255-272.

Larroque, C., Delouis, B., Sage, F., Régnier, M., Béthoux, N., Courboulex, F., et al. (2016). The sequence of moderate-size earthquakes at the junction of the Ligurian basin and the Corsica margin (western Mediterranean): The initiation of an active deformation zone revealed? Tectonophysics, 676, 135-147.

Larroque, C., Scotti, O., \& Ioualalen, M. (2012). Reappraisal of the 1887 Ligurian earthquake (western Mediterranean) from macroseismicity, active tectonics and tsunami modelling: Reappraisal of the 1887 Ligurian earthquake. Geophysical Journal International, 190, 87-104.

Laurendeau, A., Courboulex, F., Bonilla, L. F., Alvarado, A., Alfonso, Naya V., Mercerat, D., et al. (2017). Low frequency seismic amplification in the quito basin (ecuador) revealed by accelerometric recordings of the RENAC network. Bulletin of the Seismological Society of America, 107(6), 2917-2926.

Li, C., Hao, H., Li, H., Bi, K., \& Chen, B. (2017). Modeling and simulation of spatially correlated ground motions at multiple onshore and offshore sites. Journal of Earthquake Engineering, 21(3), 359-383.

Locat, J., \& Lee, H. J. (2002). Submarine landslides: Advances and challenges. Canadian Geotechnical Journal, 39, 193-212. https://doi.org/10.1139/t01-089.

Lofi, J., Déverchère, J., Gaullier, V., Gillet, H., Gorini, C., Guennoc, P., et al. (2011). Atlas of the "Messinian Salinity Crisis" seismic markers in the Mediterranean and Black seas. CCGM \& Mémoire Société Géologique de France, 179, 72.

Meunier, P., Hovius, N., \& Haines, A. J. (2007). Regional patterns of earthquake-triggered landslides and their relation to ground motion. Geophysical Research Letters, 34(20). https://doi.org/10. 1029/2007GL031337

Migeon, S., Cattaneo, A., Hassoun, V., Dano, A., Casedevant, A., \& Ruellan, E. (2012). Failure processes and gravity-flow transformation revealed by high-resolution AUV swath bathymetry on the Nice continental slope (Ligurian Sea). In: Y. Yamada et al. (Eds.), Submarine mass movements and their consequences. Advances in natural and technological hazards research (Vol. 31). Dordrecht: Springer. https://doi.org/10.1007/978-94-0072162-3_40

Migeon, S., Cattaneo, A., Hassoun, V., Larroque, C., Corradi, N., Fanucci, F., et al. (2011). Morphology, distribution and origin of recent submarine landslides of the Ligurian Margin (Northwestern Mediterranean): Some insights into geohazard assessment. Marine Geophysical Research, 32, 225-243.

Migeon, S., Mulder, T., Savoye, B., \& Sage, F. (2006). The Var turbidite system (Ligurian Sea, northwestern Mediterranean)morphology, sediment supply, construction of turbidite levee and sediment waves: Implications for hydrocarbon reservoirs. GeoMarine Letters, 26, 361-371. https://doi.org/10.1007/s00367006-0047-x.

Milana, G., Cultrera, G., Bordoni, P., Bucci, A., Cara, F., Cogliano, R., et al. (2019). Local site effects estimation at Amatrice (Central Italy) through seismological methods. Bulletin of Earthquake Engineering, 1-27. https://doi.org/10.1007/s10518019-00587-3

Mulder, T., Savoye, B., \& Syvitski, J. P. M. (1997). Numerical modelling of a mid-sized gravity flow: The 1979 Nice turbidity current (dynamics, processes, sediment budget and seafloor impact). Sedimentology, 44, 305-326.

Nakamura, Y. (1989). A method for dynamic characteristics estimation of subsurface using microtremor on the ground surface. Railway Technical Research Institute, Quarterly Reports, 30, 25-33.

Nakamura, T., Takenaka, H., Okamoto, T., Ohori, M., \& Tsuboi, S. (2015). Long-period ocean-bottom motions in the source areas of large subduction earthquakes. Scientific reports, 5, 16648.

Nocquet, J. M. (2012). Present-day kinematics of the Mediterranean: A comprehensive overview of GPS results. Tectonophysics, 579, 220-242.

Piper, D. J., Cochonat, P., \& Morrison, M. L. (1999). The sequence of events around the epicentre of the 1929 Grand Banks earthquake: Initiation of debris flows and turbidity current inferred from sidescan sonar. Sedimentology, 46(1), 79-97.

Piper, D. J., \& Savoye, B. (1993). Processes of late Quaternary turbidity current flow and deposition on the Var deep-sea fan, north-west Mediterranean Sea. Sedimentology, 40(3), 557-582.

Priest, G. R., Witter, R. C., Zhang, Y. J., Goldfinger, C., Wang, K., \& Allan, J. C. (2017). New constraints on coseismic slip during southern Cascadia subduction zone earthquakes over the past 4600 years implied by tsunami deposits and marine turbidites. Natural Hazards, 88(1), 285-313. https://doi.org/10.1007/ s11069-017-2864-9.

Ratzov, G., Cattaneo, A., Babonneau, N., Déverchère, J., Yelles, K., Bracene, R., et al. (2015). Holocene turbidites record earthquake supercycles at a slow-rate plate boundary. Geology, 43(4), 331-334. 
Régnier, J., Cadet, H., \& Bard, P. Y. (2016). Empirical quantification of the impact of nonlinear soil behavior on site response. Bulletin of the Seismological Society of America, 106(4), 1710-1719.

Rehault, J. P., \& Bethoux, N. (1984). Earthquake relocation in the Ligurian Sea (Western Mediterranean): Geological interpretation. Marine Geology, 55(3-4), 429-445.

RESIF. (1995). RESIF-RAP French Accelerometric Network; RESIF-Réseau Sismologique et géodésique Français. https:// doi.org/10.15778/resif.ra.

RESIF. (1995). RESIF-RLBP French Broad-band Network, RESIF-RAP strong motion network and other seismic stations in metropolitan France; RESIF-Réseau Sismologique et géodésique Français. https://doi.org/10.15778/resif.fr.

Roesner, A., Wiemer, G., Kreiter, S., Wenau, S., Wu, T. W., Courboulex, F., et al. (2019). Impact of seismicity on Nice slope stability-Ligurian Basin. SE France: A geotechnical revisit. Landslides, 16(1), 23-35.

Rohmer O., Bertrand E., Mercerat E.D., Régnier J., Pernoud M., Langlaude P \& Alvarez M. (2019). Combining borehole logstratigraphies and ambient vibration data to build a 3D Model of the Lower Var Valley, Nice (France), under minor revision. Eng Geol.

Salichon, J., Kohrs-Sansorny, C., Bertrand, E., \& Courboulex, F. (2010). A Mw 63 earthquake scenario in the city of Nice (southeast France): Ground motion simulations. Journal of Seismology, 14(3), 523-541.

Sanchez-Sesma, F. J., \& Crouse, C. B. (2015). Effects of site geology on seismic ground motion: Early history. Earthquake Engineering \& Structural Dynamics, 44, 1099-1113.

Semblat, J. F., Duval, A. M., \& Dangla, P. (2000). Numerical analysis of seismic wave amplification in Nice (France) and comparisons with experiments. Soil Dynamics and Earthquake Engineering, 19(5), 347-362.

Semblat, J.-F., Kham, M., \& Bard, P.-Y. (2008). Seismic-wave propagation in alluvial basins and influence of site-city interaction. Bulletin of the Seismological Society of America, 98(6), 2665-2678.

Séranne, M. (1999). The Gulf of Lion continental margin (NW Mediterranean) revisited by IBS: An overview. Geological Society, London, Special Publications, 156(1), 15-36.
St Fleur, S., Bertrand, E., Courboulex, F., Mercier de Lépinay, B., Deschamps, A., Hough, S., et al. (2016). Site effects in Port-auPrince (Haiti) from the analysis of spectral ratio and numerical simulations. Bulletin of the Seismological Society of America, 106(3), 1298-1315. https://doi.org/10.1785/0120150238.

Stegmann, S., \& Kopf, A. (2014). How stable is the Nice slope?An analysis based on strength and cohesion from ring shear experiments. In Submarine mass movements and their consequences (pp. 189-199). Cham: Springer.

Stegmann, S., Sultan, N., Kopf, A., Apprioual, R., \& Pelleau, P. (2011). Hydrogeology and its effect on slope stability along the coastal aquifer of Nice, France. Marine Geology, 280(1-4), 168-181.

Steiner, A., Kopf, A. J., Henry, P., Stegmann, S., Apprioual, R., \& Pelleau, P. (2015). Cone penetration testing to assess slope stability in the 1979 Nice landslide area (Ligurian Margin, SE France). Marine Geology, 369, 162-181. https://doi.org/10.1016/ j.margeo.2015.08.008.

Stockwell, R. G., Mansinha, L., \& Lowe, R. P. (1996). Localization of the complex spectrum: The $\mathrm{S}$ transform. IEEE Transactions on Signal Processing, 44(4), 998-1001.

Sultan, N., Cochonat, P., Canals, M., Cattaneo, A., Dennielou, B., Haflidason, H., et al. (2004). Triggering mechanisms of slope instability processes and sediment failures on continental margins: A geotechnical approach. Marine Geology, 213(1-4), 291-321. https://doi.org/10.1016/j.margeo.2004.10.011.

Sultan, N., Savoye, B., Jouet, G., Leynaud, D., Cochonat, P., Henry, P., et al. (2010). Investigation of a possible submarine landslide at the Var delta front (Nice continental slope, southeast France). Canadian Geotechnical Journal, 47, 486-496. https:// doi.org/10.1139/T09-105.

Tromp, J., Komatitsch, D., \& Liu, Q. (2008). Spectral-element and adjoint methods in seismology. Communications in Computational Physics, 3(1), 1-32.

Wartman, J., Dunham, L., Tiwari, B., \& Pradel, D. (2013). Landslides in eastern Honshu induced by the 2011 Tohoku earthquake. Bulletin of the Seismological Society of America, 103(2B), 1503-1521.

Yamanaka, H., Seo, K., \& Samano, T. (1989). Effects of sedimentary layers on surface-wave propagation. Bulletin of the Seismological Society of America, 79(3), 631-644. 